University of Nebraska - Lincoln

DigitalCommons@University of Nebraska - Lincoln

Faculty Papers and Publications in Animal

Science

Animal Science Department

1997

\title{
Divergent Selection for Heat Loss in Mice: I. Selection Applied and Direct Response Through Fifteen Generations
}

\author{
Merlyn K. Nielsen \\ University of Nebraska-Lincoln, mnielsen1@unl.edu \\ L. D. Jones \\ University of Nebraska-Lincoln \\ B. A. Freking \\ University of Nebraska-Lincoln, brad.freking@ars.usda.gov \\ J. A. DeShazer \\ University of Idaho
}

Follow this and additional works at: https://digitalcommons.unl.edu/animalscifacpub

Part of the Animal Sciences Commons

Nielsen, Merlyn K.; Jones, L. D.; Freking, B. A.; and DeShazer, J. A., "Divergent Selection for Heat Loss in Mice: I. Selection Applied and Direct Response Through Fifteen Generations" (1997). Faculty Papers and Publications in Animal Science. 505.

https://digitalcommons.unl.edu/animalscifacpub/505

This Article is brought to you for free and open access by the Animal Science Department at DigitalCommons@University of Nebraska - Lincoln. It has been accepted for inclusion in Faculty Papers and Publications in Animal Science by an authorized administrator of DigitalCommons@University of Nebraska - Lincoln. 


\title{
Divergent Selection for Heat Loss in Mice: I. Selection Applied and Direct Response Through Fifteen Generations ${ }^{1,2}$
}

\author{
M. K. Nielsen3, L. D. J ones, B. A. Freking, and J. A. Deshazer4
}

Department of Animal Science, University of Nebraska-Lincoln, Lincoln 68583-0908

ABSTRACT: Divergent selection for heat production/loss $\left(\mathrm{kcal} \cdot \mathrm{kg}^{-} \cdot 75 \cdot \mathrm{d}^{-1}\right)$, measured in 9- to 11-wk-old male mice, was conducted for 15 generations. Heat loss was measured for $15 \mathrm{~h}$ on individual animals placed overnight in direct, gradient-layer calorimeters. Selection for high $(\mathrm{MH})$ and low $(\mathrm{ML})$ heat loss and unselected control (MC) occurred in each of three replicates for a total of nine unique lines. Repeatability of the heat loss measurement was .45 and the $\mathrm{CV}$ was $10.5 \%$. Cumulative realized selection differentials, averaged for the three replicates, were 145.1 and $-105.0\left(\mathrm{kcal} \cdot \mathrm{kg}^{-.75} \cdot \mathrm{d}^{-1}\right)$ and ranged from
136.9 to 149.2 and -107.1 to -101.3 for $\mathrm{MH}$ and $\mathrm{ML}$ selection, respectively. Cumulative standardized realized selection differentials, averaged for the three replicates, were 10.06 and -9.51 for $\mathrm{MH}$ and $\mathrm{ML}$ selection, respectively. Direct responses $\left(\mathrm{kcal} \cdot \mathrm{kg}^{-} \cdot 75 \cdot \mathrm{d}^{-1}\right)$ in heat loss after 15 generations were 44.2 for $\mathrm{MH}$ and -27.4 for $\mathrm{ML}$ as deviations from MC. Asymmetry of response was evident $(P=.03)$ by Generation 10. Realized heritability was .28 \pm .01 based on divergence of $\mathrm{MH}$ and $\mathrm{ML}$ selection. For selection for higher and lower heat loss, realized heritabilities were $.31 \pm .01$ and $.26 \pm .01$, respectively.

Key Words: Mice, Heat Loss, Energy Metabolism, Selection

J. Anim. Sci. 1997. 75:1461-1468

\section{Introduction}

Cost of feed is one of the largest economic inputs in livestock production. Among the costs of nutrients from feed, energy to meet metabolic functions constitutes the largest fraction. Meeting maintenance requirements is a larger fraction of the life cycle energy input than energy used directly for productive functions. Studies that have partitioned energy utilization have usually found much more evidence for genetic variation in amount of energy used for maintenance of a given size of animal than for energy used solely for producing a given amount of product.

Selection to change energy used for maintenance would be of high interest. However, measurement of

${ }^{1}$ Published as paper no. 11605, J ournal Ser., Nebraska Agric. Res. Div., Univ. of Nebraska, Lincoln 68583-0908.

${ }^{2} \mathrm{Help}$ with data collection and animal management by J. D. Hauptman, E.L.A. Ribeiro, and several laboratory assistants, and suggestions and counsel from G. E. Dickerson, R. A. Britton, T. G. J enkins, C. L. Ferrell, K. A. Leymaster, P. S. Miller, and S. M. J ones are gratefully appreciated.

${ }^{3}$ To whom correspondence should be addressed: A218 Animal Science.

${ }^{4}$ Current address: Dept. of Agric. Engineering, Univ. of Idaho, Moscow, ID 83844-2040.

Received J uly 31, 1996.

Accepted J anuary 9, 1997. individual feed intake and attempting to partition intake into that used only for maintenance in young animals, to enable selection decisions shortly after puberty, are difficult or expensive. Because energy that is metabolized but not stored in a product must be lost, measurement of heat loss gives another alternative, especially if it can be performed in animals that are eating mainly to meet maintenance.

We practiced 15 generations of selection for high and low heat loss of mature mice measured in direct calorimeters. The objectives of this research were to measure the magnitudes of selection applied and direct responses realized and to estimate realized heritability for a single measurement of heat loss.

\section{Materials and Methods}

Measurement of Heat Loss. Ten direct, gradientlayer, individual-animal calorimeters were constructed and put into operation in our small animal laboratory. The units were purchased from Thermonetics Corporation (San Diego, CA; model 0601-S, gradient-layer Seebeck envelope). Heat energy is measured as the level of electrical voltage created as energy passes through the different gradients; the voltage is directly proportional to the amount of heat energy passing through the walls of 
the calorimeter. There are 2,500 sensors in the six walls of each unit that are tied together into one electrical line.

Each unit has a removable lid. The interior of the unit is a cube with dimensions of $18.5 \mathrm{~cm}$ and, when in operation, a mouse is placed into a stainless steel cage (a cube with dimensions of $15 \mathrm{~cm}$; the bottom and lowest $4 \mathrm{~cm}$ of each side is solid; the rest of the sides and top is a screen with $1.3-\mathrm{cm}$ openings) that is positioned inside the calorimeter chamber. When the unit is in operation, air is constantly pumped through the calorimeter, and water is also constantly circulated through a tubing system in the six walls of the calorimeter to ensure steady heat transfer from the interior of the chamber, hence the mouse, through the six walls.

The units were linked in banks of five to two data acquisition systems. Each system has an analog-todigital conversion unit that measures the voltage output from each of the five calorimeters and converts that reading to a character string for input into a computer. Each of the two computers was programmed to collect data every minute during the collection period. Each calorimeter has its own unique calibration for voltage to calories of heat crossing the walls of the calorimeter.

Because the measurement would take place in the dark for the mouse and because mice are nocturnal, the time of measurement was set for overnight. An animal was weighed at approximately 1630 , placed in the stainless steel cage with a 3.5-g pellet of feed, and then sealed in the calorimeter. The data collection program was initiated in the computers, and after a 30-min acdimation period, heat loss was collected every minute for a continuous $15-h$ period. The next morning, the mice were taken from the calorimeters and returned to their rearing cages, and the average heat loss $\left(\mathrm{kcal} \cdot \mathrm{kg}^{-} \cdot 75 \cdot \mathrm{d}^{-1}\right)$ for the 15 -h period was printed from the computer and recorded. Assuming no change in the body temperature of a mouse, heat loss measured in the calorimeter would be equal to total heat production.

The units were calibrated using biological standards. Ten animals were each measured in all the calorimeters over a 10-d period following a $10 \times 10$ Latin-square design. The cal orimeters were calibrated to give the same reading for the average of the 10 animals. Data from this same design were used to estimate between- and within-animal components of variance for the heat measurement, and an estimate of repeatability of the measurement was derived.

Experimental Animals and Selection Process. The population of mice was a four-way composite developed in our laboratory and was described earlier by J ones et al. (1992). At least 40 males and 40 females of each of four outbred stocks were brought into the laboratory from Charles River (CR) and Harlan Sprague Dawley (HSD) laboratories to start the composite. They were as follows: A = HSD, NIH strain;
$B=H S D, I C R$ strain; $C=C R, C F-1$ strain; and D = $\mathrm{CR}, \mathrm{CFW}(\mathrm{Sw})$ strain. In the first generation of crossing, both reciprocal crosses of $A$ and $B$ and of $C$ and $D$ produced two-way crosses $(A B, B A, C D$, and $D C)$. In the second generation, four-way crosses were produced as follows: $A B \times C D, B A \times D C, C D \times A B$, and DC $\times$ BA.

The experiment was carried out in three replicates. As the first generation of four-way crosses was being produced, one-third was mated to have litters at $8 \mathrm{wk}$, one-third at $10 \mathrm{wk}$, and one-third at $12 \mathrm{wk}$ of age. Matings of the $F_{1}$ four-way crosses to produce secondgeneration $\left(\mathrm{F}_{2}\right)$ offspring were done at the same three ages as for their parents, thus yielding three breeding groups that were separated by 4 wk at their time of littering. This then gave rise to the three replicates.

During the selection phase, breeder males and females were placed in mating cages at 12 wk of age and litters were produced at 15 wk. Only one parity was produced from breeders; thus, the generation interval was $15 \mathrm{wk}$. There were three criteria for selection: $\mathbf{M H}=$ selection for high heat loss $\left(\mathrm{kcal} \cdot \mathrm{kg}^{-} \cdot 75 \cdot \mathrm{d}^{-1}\right), \mathbf{M L}=$ selection for low heat loss, and MC = no intentional selection. Three replicates of selection using three criteria for choosing breeder animals gave rise to nine unique lines. Within a replicate, the $M H, M L$, and $M C$ selection lines all had the same grandparents in the base generation.

After measurement of heat loss in Generation 0 animals ( $F_{2}$ generation of the four-way composite), the three replicates were separated one more week and were maintained thereafter with a 5-wk interval between the same point in the life cycle. That is, if Replicate 1 was having litters born, 5 wk later Replicate 2 would be having litters born, and $10 \mathrm{wk}$ later Replicate 3 would be having litters born.

Sixteen litters provided the animals for measurement and for breeding in each line in each generation. At birth, litters were reduced to eight pups, if larger than eight, with an ideal sex ratio of five males:three females. For measurement of heat loss, only males were used. Except for Generation 0, animals were measured between 9 and 11 wk of age. In Generation 0 , the calorimetry equipment was not operational when the animals were 9 to 11 wk of age; thus, measurement was delayed, and the males were 20 to $22 \mathrm{wk}$ old. From the 16 litters, the intended number of males was 80 ( 16 litters $\times 5$ males each), but it varied from approximately 72 to 80 . In the $\mathrm{MH}$ and $\mathrm{ML}$ selection lines, all males were measured, and the top 18 for the criterion were selected for mating, each to two females. The females came from the 16 litters, and we tried to have two randomly chosen sisters mated to a given male whenever possible. The extra two males that were mated (ranking 17th and 18th) were for substitutes if the top 16 did not produce a litter. Likewise, two females, instead of only one, were mated to each selected male to guard against barren females, lost litters, or less desirable sex ratios in the 
litters. No intentional selection was practiced within a mating sire to keep a litter that was larger, but the one that was closer to the five male:three female ratio with strong or older pups was usually selected.

In the MC lines, 16 litters provided the males for measurement and the females for mating in each generation. In Generations 6, 10, and 15, all males were measured, and the numbers were very similar to that in the contemporary $\mathrm{MH}$ and $\mathrm{ML}$ lines (i.e., between 72 and 80 ). In all other generations, between 20 and 35 animals were measured with animals sampled as evenly as possible from each of the 16 litters. One male was chosen from each litter to be mated to two females of a different litter, and matings of a "spare" 17th male, serving the same role as the matings of the 17th and 18th ranking males in the $\mathrm{MH}$ and $\mathrm{ML}$ lines, were also carried out. Matings were assigned to have accumulated inbreeding as similar in the $\mathrm{MC}$ as in the $\mathrm{MH}$ and $\mathrm{ML}$ selection lines.

Measurement of Selection Differentials. Because measurement of heat loss was performed only in males, realized cumulative selection differentials were calculated similar to the method used by Gion et al. (1990), the only difference being the characteristic here was measured on males as opposed to females. Cumulative selection differentials (CSD) were calculated as follows:

$$
\operatorname{CSD}_{n}=.5 M_{n-1}+.25 \sum_{i=0}^{n-2} \text { when }^{n \geq 2}\left(M_{i}+F_{i}\right) \text {, }
$$

where $\mathrm{n}$ is the number of generations of selection completed and $\mathrm{M}$ and $\mathrm{F}$ are "male" and "female" selection differentials. Differentials for males (M) were calculated by weighting the deviation of a selected male's record from the generation mean by the number of his sons that had records the next generation. Female differentials (F) were calculated by weighting the deviation of the selected male's record by the number of grandsons (through daughters) that had records. Because heat loss was measured only in a sample of animals in MC lines in most generations, cumulative selection differentials could only be calculated in $\mathrm{MH}$ and $\mathrm{ML}$ lines but were expected to be zero in MC.

In addition, cumulative intended selection differentials and cumulative standardized selection differentials were also calculated for the $\mathrm{MH}$ and $\mathrm{ML}$ selection lines. Intended selection differentials were calculated by deviating the average of the 16 highest-ranking males for $\mathrm{MH}$, or lowest for $\mathrm{ML}$, from the generation mean, regardless of whether these animals reproduced. Cumulative intended selection differentials were then computed as one-half the sum of all the previous generations' intended selection differentials. Standardized selection differentials were calculated by dividing each animal's deviation by the standard deviation in each generation-line subclass.
Cumulative standardized selection differentials were then calculated in the same manner as shown above, weighting "male" and "female" contributions by the numbers of records in the son and grandson generations.

Statistical Analyses. Realized cumulative selection differentials, phenotypic standard deviations, and cumulative standardized selection differentials for heat loss were regressed on generation number within each replicate. Regressions of divergence of response (difference in means, $\mathrm{MH}-\mathrm{ML}$ ) on generations were calculated within each replicate. Regressions of divergence of response $(\mathrm{MH}-\mathrm{ML})$ on cumulative selection differentials $(M H-M L)$ were calculated for each replicate. For each type of regression, the average across replicates was then calculated. Standard errors for the average regressions were calculated empirically from the variation among estimates from the three replicates, thus accounting for variability due to drift. The average estimates were then tested for significance from zero using a t distribution with $2 \mathrm{df}$.

Using data from Generations 6, 10, and 15 when all animals in the $\mathrm{MC}$ lines were measured, ratios of $\mathrm{MH}$ - ML, $M H-M C$, and $M L-M C$ means for heat loss to generation numbers and to cumulative selection differentials were calculated within each replicate. As with the regressions, the average ratio across replicates was computed and the standard errors were derived using the variation among the three replicates.

Finally, the nine replicate-selection criterion means for heat loss in Generations 6, 10, and 15 were also tested for criteria differences using a model of replicate + criterion + replicate $\times$ criterion interaction (the error for criteria effects). Selection criteria means were compared using orthogonal contrasts of 1 ) $\mathrm{MH}$ vs ML to test for the effect of selection and 2) $(\mathrm{MH}+\mathrm{ML}) / 2$ vs $\mathrm{MC}$ to test for asymmetry of selection.

\section{Results and Discussion}

Variation and Repeatability of the Heat Loss Measurement. The CV of heat loss per metabolic size per day, as measured in Generations 0 and 1 animals, was $10.5 \%$. Heat loss is similar to a weight measurement in relative variability. From the experiment of repeated measurement of 10 animals in all 10 calorimeters, the estimate of repeatability was .45.

Selection Applied. Cumulative intended, realized, and the standardized realized selection differentials after 15 generations of selection for high and low heat loss are given in Table 1 . The cumulative realized and standardized realized selection differentials for each generation are presented in Appendix Tables 1 and 2 .

Realized cumulative selection differentials were similar to intended cumulative selection differentials. The proportion of selection intended that was achieved 
Table 1. Cumulative intended, realized, and standardized selection differentials for heat loss $\left(\mathrm{kcal} \cdot \mathrm{kg}^{-.75} \cdot \mathrm{d}^{-1}\right)$ after 15 generations of selection

\begin{tabular}{lccc}
\hline \hline $\begin{array}{l}\text { Criterion }^{a} \\
\text { and replicate }\end{array}$ & Intended & Realized & $\begin{array}{c}\text { Standard } \\
\text { realized }\end{array}$ \\
\hline MH & & & \\
1 & 138.8 & 136.9 & 10.15 \\
2 & 152.9 & 149.2 & 9.82 \\
3 & 152.5 & 149.2 & 10.18 \\
Mean & 147.9 & 145.1 & 10.06 \\
ML & & & \\
1 & -109.5 & -106.6 & -9.40 \\
2 & -103.3 & -101.3 & -9.42 \\
3 & -107.1 & -107.1 & -9.72 \\
Mean & -106.7 & -105.0 & -9.51 \\
\hline
\end{tabular}

$\mathrm{a} \mathrm{MH}=$ high heat loss; $\mathrm{ML}=$ low heat loss.

ranged from 97.3 to $100 \%$ and averaged $98 \%$. A very high proportion of the males ranking in the top 16 on their respective criteria produced sons and grandsons that were measured, and there was no apparent relationship between rank of a sire and numbers of progeny and grandprogeny.

The regression of realized cumulative selection differential on generation number ranged from 9.41 to 10.29 in the $\mathrm{MH}$ and from -6.69 to -7.12 in the $\mathrm{ML}$ across the three replicates; the averages were $9.75 \pm$ .27 and $-6.85 \pm .13$ for the $\mathrm{MH}$ and $\mathrm{ML}$, respectively. In the observed scale, the cumulative selection differentials for increased heat loss were about $40 \%$ greater than cumulative differentials for decreased heat loss.

However, variability in heat loss also changed with the mean over generations of selection. Regressions of the standard deviation of heat loss $\left(\mathrm{kcal} \cdot \mathrm{kg}^{-.75} \cdot \mathrm{d}^{-1}\right)$ on generation number ranged from .21 to .30 for $\mathrm{MH}$ and from -.10 to -.27 for $M L$ selection across the three replicates. The average changes in standard deviation per generation were $.27 \pm .02$ and $-.17 \pm .05$ for $\mathrm{MH}$ and $M L$, respectively. When selection differentials were calculated on a standardized basis, the cumulative selection differentials were similar between $\mathrm{MH}$ and ML selection. Regressions of cumulative standardized selection differentials on generation number were between .65 and .69 for $\mathrm{MH}$ selection and between -.65 and -.63 for $M L$. The average for $M L$ $(-.64 \pm .01)$ was $95 \%$ as large as the average for $\mathrm{MH}$ selection (.66 \pm .01$)$.

Based on the number measured (72 to 80 ) and selected (top 16 intended), one would expect a standardized selection differential, assuming a normal distribution, of approximately .67 to .68 each generation. This was achieved in the $\mathrm{MH}$ selection, but the realized differentials were somewhat smaller in the ML selection. Evidently our measurement of heat loss is not strictly normally distributed; it seems to be skewed slightly to the right.
As a check on possible correlated unintentional selection for body mass, cumulative selection differentials were calculated in the same manner (male trait only) as those for heat loss. Body mass of the animal as it entered the calorimeter was the measurement. Average changes per generation in cumulative selection differentials for body mass were $.02 \pm .08 \mathrm{~g}$ in the $\mathrm{MH}$ selections and $.04 \pm .02 \mathrm{~g}$ in the $\mathrm{ML}$. Thus, there was essentially no secondary selection for either large or small body mass in either the ML or $\mathrm{MH}$ selection.

Response over 15 Generations. Figure 1 gives a graphical presentation of the mean heat loss for $\mathrm{MH}$, $M L$, and $M C$ selection criteria, averaged for the three replicates, across the 15 generations of selection. Figure 2 shows the similarity of the three replicates for mean heat loss of $M H, M L$, and $M C$ lines. Because the animals were 20 to $22 \mathrm{wk}$ old at measurement in Generation 0, the heat loss was lower than for animals at the intended measurement age of 9 to $11 \mathrm{wk}$. Regressions of divergence in response $(\mathrm{MH}-\mathrm{ML})$ on generation number over the 15 generations and the ratios of divergence in response $(\mathrm{MH}-\mathrm{ML})$ and response in each direction as a deviation from the control (MH - MC and ML - MC) after 6, 10, and 15 generations are listed in Table 2 . The means for heat loss of each line for each generation are in Appendix Table 3. All tests of significance for the rate of response were significantly different from zero ( $\mathrm{P}<$ $.001)$.

The average change $\left(\mathrm{kcal} \cdot \mathrm{kg}^{-} \cdot 75 \cdot \mathrm{d}^{-1}\right)$ per generation in $\mathrm{MH}-\mathrm{ML}$ was $4.70 \pm .09$, when estimated by regression over the 15 generations of selection, and $4.78 \pm .08$ when dividing the Generation 15 difference by 15 generations of selection. At Generation 6, the rate of change in $\mathrm{MH}-\mathrm{ML}$ was somewhat smaller. Of particular note is that rate of response, measured by divergence between high and low selection, did not slow after the initial six generations. At Generation 6,

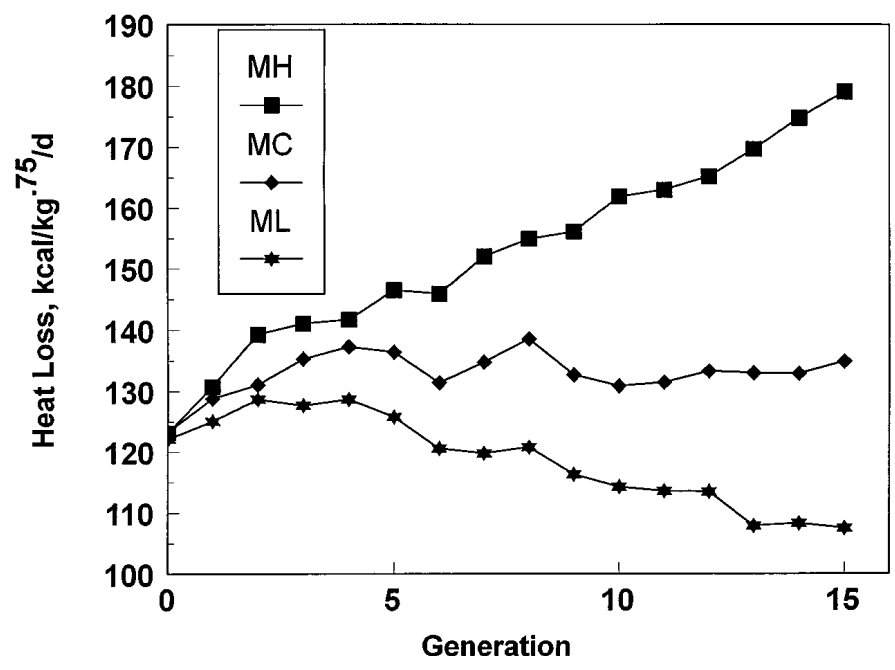

Figure 1. Mean heat loss in each generation, averaged across the three replicates, for high (MH), low (ML), and control (MC) selection. 


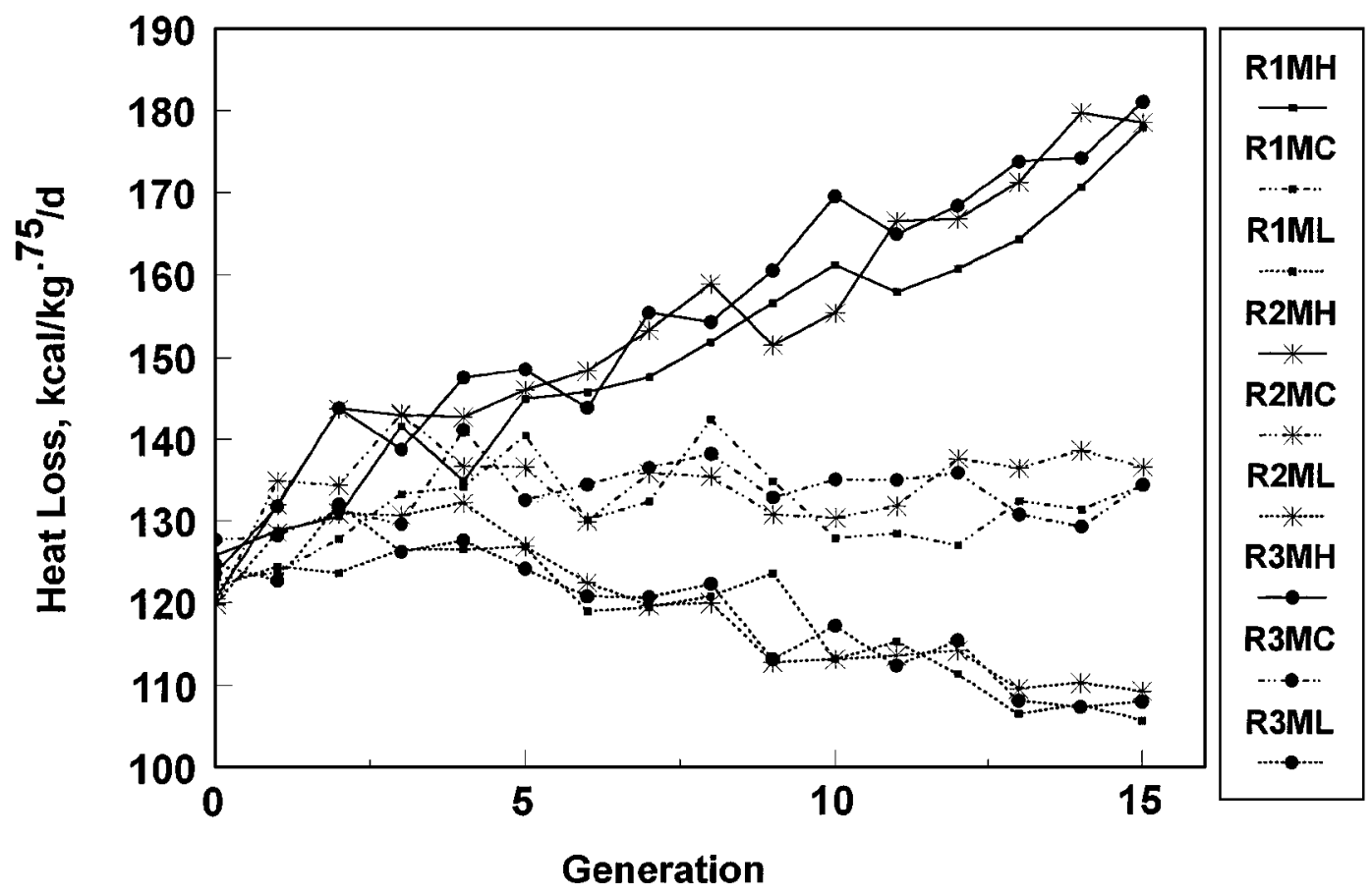

Figure 2. Mean heat loss in each generation for high (MH), low (ML), and control (MC) selection in each of the three replicates (R1, $R 2$, and $R 3)$.

response in the up direction ( $\mathrm{MH}-\mathrm{MC}$ ) was $35 \%$ greater than response in the down direction (ML $\mathrm{MC}$ ). At Generation 10, response to up-selection was $85 \%$ greater than response to down-selection. After 15 generations, response was $60 \%$ greater for up- than for down-selection. Response to high selection was responsible for $62 \%$ of the divergence, and response to low selection accounted for 38\%.

Analysis of the criteria means at Generation 6, 10, and 15 showed a highly significant $(P<.001)$ effect of selection $(\mathrm{MH}-\mathrm{ML})$. The test for asymmetry of response was not significant $(P>.30)$ at Generation 6. However, asymmetry was evident at Generation 10 ( $P=.03)$, and it was highly significant at Generation $15(\mathrm{P}<.001)$.

Realized Heritability for Heat Loss. Table 3 contains estimates of realized heritability based on regressions of response on cumulative selection differentials and the ratios of cumulative responses to cumulative selection differentials. Realized heritability, estimated by the regression of divergence between $\mathrm{MH}$ and $\mathrm{ML}$ on cumulative selection applied was .28 \pm .003 . Using the ratio of the Generation 15 difference between $\mathrm{MH}$ and $M L$ to the difference in cumulative selection differential produced a very similar estimate of realized heritability, .29 \pm .01 . Rates of response and selection applied, as a difference between $\mathrm{MH}$ and $\mathrm{ML}$ selections, were similar over the 15 generations; hence, there was the close agreement between these two methods of estimating heritability.

Because we measured all MC males at Generations 6,10 , and 15 , realized heritability for high and low selection could also be estimated by the ratio of response, deviated from $M C$, to cumulative selection applied at these points. Similar estimates for realized heritability were found for increased heat loss at each generation studied; the same was true for estimates for low heat selection. Over the 15 generations, heritability by this method was $.31 \pm .01$ for increased heat loss and $.26 \pm .01$ for decreased heat loss. Upward selection had higher realized heritability than selection in the downward direction and the difference approached significance $(P<.10)$.

Discussion. Evidence of genetic variation in maintenance energy of cattle used in beef production has been reported in comparisons of different types. Ferrell and J enkins (1985), in an extensive summary of their own work and others, reported large variation in estimates of maintenance energy per metabolic size. In most cases, cattle with higher milk production and growth potential have expressed higher maintenance requirements independent of body mass. A large proportion of the variation seems to be explained by critical organ mass, especially the liver. Work by Montaño-Bermudez et al. (1990) also showed a direct relationship between maintenance requirements and milk production of beef cattle, independent of body size. J ones et al. (1992) reported genetic variation in liver:metabolic body mass (heritability of .40) in the population of mice used to establish the present selection study; thus, it was not surprising that heat loss in mature animals would respond easily to selection. 
Table 2. Regressions over 15 generations of divergence in response (high minus low) on generation number and ratios of response as a deviation from the control to generation number after 6, 10, and 15 generations of selection for heat loss $\left(\mathrm{kcal} \cdot \mathrm{kg}^{-.75} \cdot \mathrm{d}^{-1}\right)$

\begin{tabular}{|c|c|c|c|}
\hline $\begin{array}{l}\text { Response }^{a} \\
\text { and replicate }\end{array}$ & \multicolumn{3}{|c|}{ Regression (Generations 0-15) } \\
\hline \multicolumn{4}{|l|}{ MH-ML } \\
\hline 1 & \multicolumn{3}{|c|}{4.52} \\
\hline 2 & \multicolumn{3}{|c|}{4.78} \\
\hline 3 & \multicolumn{3}{|c|}{4.79} \\
\hline \multirow[t]{2}{*}{ Mean } & \multicolumn{3}{|c|}{$4.70 \pm .09$} \\
\hline & 6 & 10 & 15 \\
\hline \multicolumn{4}{|l|}{ MH-ML } \\
\hline 1 & 4.48 & 4.81 & 4.83 \\
\hline 2 & 4.33 & 4.23 & 4.63 \\
\hline 3 & 3.87 & 5.24 & 4.88 \\
\hline Mean & $4.23 \pm .18$ & $4.76 \pm .29$ & $4.78 \pm .08$ \\
\hline \multicolumn{4}{|l|}{$\mathrm{MH}-\mathrm{MC}$} \\
\hline 1 & 2.62 & 3.34 & 2.92 \\
\hline 2 & 3.08 & 2.51 & 2.81 \\
\hline 3 & 1.58 & 3.45 & 3.13 \\
\hline Mean & $2.43 \pm .44$ & $3.10 \pm .30$ & $2.95 \pm .09$ \\
\hline \multicolumn{4}{|l|}{ ML-MC } \\
\hline 1 & -1.87 & -1.47 & -1.91 \\
\hline 2 & -1.25 & -1.75 & -1.82 \\
\hline 3 & -2.28 & -1.79 & -1.76 \\
\hline Mean & $-1.80 \pm .30$ & $-1.67 \pm .10$ & $-1.83 \pm .04$ \\
\hline
\end{tabular}

$\mathrm{a} \mathrm{MH}=$ high heat loss; $\mathrm{ML}=$ low heat loss; $\mathrm{MC}=$ control.

Direct selection has been practiced in other species for oxygen consumption, which would be highly correlated to heat production, assuming little variation in substrates oxidized. Medrano and Gall (1976) practiced selection for low oxygen consumption per unit body weight at $12 \mathrm{~d}$ of age for six generations in Tribolium. Response was very large for the first three generations, perhaps until a minimum level threshold was reached; their realized heritability was .44. MacLaury and J ohnson (1972) practiced selection in divergent lines for oxygen consumption per unit body mass in chickens at 3 wk of age. A significant response resulted, mainly from an increase in the high oxygen consumption line; the realized heritability was .07. Especially for chickens at $3 \mathrm{wk}$, measurement of oxygen consumption would be influenced heavily by metabolic processes associated with formation of products of growth, not just those for maintenance.

Kownacki et al. (1975), Kownacki and Keller (1978), and Gunsett et al. (1981) reported a reduction in basal metabolic rate or total energy required for maintenance in lines of mice selected for higher gain or feed conversion on either ad libitum or restricted feeding. Bishop and Hill (1985) reported a $13 \%$ difference in resting heat production of mature mice, measured by indirect calorimetry, between lines selected for high or low feed intake between 4 and 6 wk of age. Wang et al. (1980) and Rios et al. (1986) reported differences in heat loss per unit metabolic size in lines of rats selected for postweaning gain.

Residual feed consumption, defined as feed consumption adjusted for average size for maintenance and mass of products (e.g., body gain, eggs, and milk) produced, has shown genetic variation. Estimated realized heritability in layer populations has been near .20 (Bordas et al., 1992), and heritability estimated from the covariance between relatives has been between .40 and .60 (Luiting and Urff, 1991; Sabri et al., 1991; Schulman et al., 1994). In dairy cattle, estimates of heritability of residual feed consumption have ranged from .14 (Van Arendonk et al., 1991) to .32 (Veerkamp et al., 1995). Heritability of residual feed consumption should be similar to heritability of maintenance requirement and heat production/loss.

Relative variability and heritability of the heat loss measurement in this study were both of sizable magnitude; hence, large responses to both high and low selection occurred when applied to only one sex and with only average intensity. Care must be taken in equating total heat loss as measured here to energy for maintenance. Even though relatively mature

Table 3. Regressions over 15 generations of divergence in response (high minus low) on divergent cumulative selection differentials and ratios of responses as deviations from the control to cumulative selection differentials after 6,

10 , and 15 generations of selection for heat loss

\begin{tabular}{|c|c|c|c|}
\hline $\begin{array}{l}\text { Response }^{\mathrm{a}} \\
\text { and replicate }\end{array}$ & \multicolumn{3}{|c|}{ Regression (Generations 0-15) } \\
\hline \multicolumn{4}{|l|}{ MH-ML } \\
\hline 1 & \multicolumn{3}{|c|}{.28} \\
\hline 2 & \multicolumn{3}{|c|}{.28} \\
\hline 3 & \multicolumn{3}{|c|}{.27} \\
\hline \multirow[t]{2}{*}{ Mean } & \multicolumn{3}{|c|}{$.28 \pm .003$} \\
\hline & 6 & 10 & 15 \\
\hline \multicolumn{4}{|l|}{ MH-ML } \\
\hline 1 & .29 & .30 & .30 \\
\hline 2 & .26 & .25 & .28 \\
\hline 3 & .23 & .31 & .29 \\
\hline Mean & $.26 \pm .02$ & $.29 \pm .02$ & $.29 \pm .01$ \\
\hline \multicolumn{4}{|l|}{$\mathrm{MH}-\mathrm{MC}$} \\
\hline 1 & .32 & .37 & .32 \\
\hline 2 & .34 & .26 & .28 \\
\hline 3 & .17 & .36 & .31 \\
\hline Mean & $.28 \pm .05$ & $.33 \pm .03$ & $.31 \pm .01$ \\
\hline \multicolumn{4}{|l|}{ ML-MC } \\
\hline 1 & .25 & .20 & .27 \\
\hline 2 & .17 & .24 & .27 \\
\hline 3 & .31 & .24 & .25 \\
\hline Mean & $.24 \pm .04$ & $.23 \pm .01$ & $.26 \pm .01$ \\
\hline
\end{tabular}

$\mathrm{a} \mathrm{MH}=$ high heat loss; $\mathrm{ML}=$ low heat loss; $\mathrm{MC}=$ control. 
males were measured, the conditions for measurement were much different from the normal day-to-day life of the animals. For measurement, an animal was placed by itself for the first time in its life in a stainless steel cage with no bedding and in a totally dark, closed chamber with forced-air circulation. How this novel environment affected the mouse compared with the animal being with his life-long cohorts in a bedded cage is not known. One would expect, though, that at the very least, the animal's behavior was temporarily altered. Thus, the large line differences observed in heat loss may not be reflected to as large a magnitude for differences in energy requirements for maintenance.

\section{Implications}

Selection for heat loss per unit of metabolic size in mice, either in an upward or downward direction, produces significant changes in a population. The realized heritability is between .25 and .30 , and the coefficient of variation is approximately $10 \%$; thus, relative responses to selection are similar to that obtained when selecting for a growth measurement. Heat production/loss in non-growing, non-reproducing animals is highly correlated to feed intake or feed energy for maintenance. Changing feed intake for maintenance seems quite possible.

\section{Literature Cited}

Bishop, S. C., and W. G. Hill. 1985. Effects of selection for growth, body composition, and food intake in mice. III. Correlated responses: growth, body composition, food intake, and efficiency and catabolism. Genet. Res. 46:57.

Bordas, A., M. Tixier-Boichard, and P. Merat. 1992. Direct and correlated responses to divergent selection for residual food intake in Rhode Island Red laying hens. Br. Poult. Sci. 33:741.
Ferrell, C. L., and T. G. J enkins. 1985. Cow type and the nutritional environment: Nutritional aspects. J . Anim. Sci. 61:725.

Gion, J. M., A. C. Clutter, and M. K. Nielsen. 1990. Alternative methods of selection for litter size in mice: II. Response to thirteen generations of selection. J. Anim. Sci. 68:3543.

Gunsett, F. C., D. H. Baik, J . J . Rutledge, and E. R. Hauser. 1981. Selection for feed conversion on efficiency and growth in mice. J. Anim. Sci. 52:1280.

J ones, L. D., M. K. Nielsen, and R. A. Britton. 1992. Genetic variation in liver mass, body mass, and liver:body mass in mice. J. Anim. Sci. 70:2999.

Kownacki, M., and J. Keller. 1978. The basal metabolic rate in selected and unselected mice. Genet. Pol. 19:339.

Kownacki, M., J. Keller, and E. Gebler. 1975. Selection of mice for high weight gains-its effect on the basal metabolic rate. Ge net. Pol. 16:359.

Luiting, P., and E. M. Urff. 1991. Residual feed consumption in laying hens. 1. Quantification of phenotypic variation and repeatabilities. Poult. Sci. 70:1655.

MacLaury, D. W., and T. H. J ohnson. 1972. Selection for high and low oxygen consumption in chickens. Poult. Sci. 51:591.

Medrano, J. F., and G.A.E. Gall. 1976. Direct and correlated responses to selection for body size and oxygen consumption in Tribolium. J. Anim. Sci. 43:739.

Montaño-Bermudez, M., M. K. Nielsen, and G. H. Deutscher. 1990. Energy requirements for maintenance of crossbred beef cattle with different genetic potential for milk. J . Anim. Sci. 68:2279.

Rios, J. G., M. K. Nielsen, G. E. Dickerson, and J. A. DeShazer 1986. Selection for postweaning gain in rats: I. Correlated response in feed utilization and body composition. J . Anim. Sci. 63:34.

Sabri, H. M., C. J. Wilcox, H. R. Wilson, and R. H. Harms. 1991. Measurements of genetic variation in residual metabolizable energy intake of laying hens. Poult. Sci. 70:222.

Schulman, N., M. Tuiskula-Haavists, L. Siitonen, and E. A. Mäntysaari. 1994. Genetic variation of residual feed consumption in a selected Finnish egg-layer population. Poult. Sci. 73:1479.

Van Arendonk, J .A.M., G. J . Nieuwhof, H. Vos, and S. Korven. 1991. Genetic aspects of food intake and efficiency in lactating dairy heifers. Livest. Prod. Sci. 29:263.

Veerkamp, R. F., G. C. Emmons, A. R. Cromie, and G. Simm. 1995. Variance components for residual food intake in dairy cows. Livest. Prod. Sci. 41:111.

Wang, C. T., G. E. Dickerson, S. E. Hadden, and J . A. DeShazer. 1980. Feed utilization of rats selected for rate and for efficiency of lean growth. Z. Tierz. Zuechtungsbiol. 97:217.

Appendix Table 1. Cumulative selection differentials over 15 generations of selection for high $(\mathrm{MH})$ or low $(\mathrm{ML})$ heat loss $\left(\mathrm{kcal} \cdot \mathrm{kg}^{-.75} \cdot \mathrm{d}^{-1}\right)$ in three replicates

\begin{tabular}{rrrrrrrrr}
\hline \hline & \multicolumn{2}{c}{ Replicate 1} & & \multicolumn{2}{c}{ Replicate 2} & & \multicolumn{2}{c}{ Replicate 3 } \\
\cline { 2 - 3 } \cline { 7 - 8 } & MH & ML & & MH & ML & & MH & ML \\
\hline 1 & 7.8 & -7.3 & & 7.7 & -7.1 & & 7.2 & -8.5 \\
2 & 15.4 & -15.8 & & 16.1 & -15.0 & & 15.3 & -15.4 \\
3 & 23.7 & -22.6 & & 25.1 & -20.8 & & 25.6 & -23.9 \\
4 & 32.3 & -29.5 & & 33.4 & -30.3 & & 34.3 & -30.2 \\
5 & 40.7 & -37.0 & & 44.1 & -38.0 & & 46.4 & -36.8 \\
6 & 48.9 & -43.9 & & 54.4 & -44.3 & & 54.7 & -44.2 \\
7 & 58.7 & -50.2 & & 65.4 & -51.0 & & 64.8 & -50.5 \\
8 & 67.9 & -57.9 & & 76.9 & -57.4 & & 74.0 & -57.7 \\
9 & 78.7 & -64.6 & & 86.5 & -65.0 & & 84.1 & -65.4 \\
10 & 89.3 & -72.8 & & 95.8 & -71.5 & & 96.9 & -74.1 \\
11 & 98.4 & -81.0 & & 108.2 & -77.2 & & 108.2 & -81.1 \\
12 & 109.8 & -87.7 & & 119.3 & -83.8 & & 118.4 & -87.8 \\
13 & 119.7 & -94.0 & & 128.2 & -89.8 & & 128.6 & -94.9 \\
14 & 126.6 & -99.6 & & 138.7 & -95.9 & & 138.5 & -100.6 \\
15 & 136.9 & -106.6 & & 149.2 & -101.3 & & 149.2 & -107.1 \\
\hline
\end{tabular}


Appendix Table 2. Cumulative standardized selection differentials over 15 generations of selection for high $(\mathrm{MH})$ or low $(\mathrm{ML})$ heat loss in three replicates

\begin{tabular}{|c|c|c|c|c|c|c|}
\hline \multirow[b]{2}{*}{ Generation } & \multicolumn{2}{|c|}{ Replicate 1} & \multicolumn{2}{|c|}{ Replicate 2} & \multicolumn{2}{|c|}{ Replicate 3} \\
\hline & $\mathrm{MH}$ & $M L$ & $\mathrm{MH}$ & $M L$ & $\mathrm{MH}$ & $M L$ \\
\hline 1 & .67 & -.58 & .70 & -.59 & .68 & -.62 \\
\hline 2 & 1.31 & -1.26 & 1.36 & -1.23 & 1.32 & -1.28 \\
\hline 3 & 2.04 & -1.86 & 2.02 & -1.80 & 1.99 & -1.94 \\
\hline 4 & 2.75 & -2.47 & 2.66 & -2.44 & 2.61 & -2.61 \\
\hline 5 & 3.43 & -3.14 & 3.26 & -3.05 & 3.26 & -3.24 \\
\hline 6 & 4.07 & -3.79 & 3.94 & -3.61 & 3.91 & -3.81 \\
\hline 7 & 4.79 & -4.40 & 4.58 & -4.24 & 4.62 & -4.43 \\
\hline 8 & 5.44 & -5.17 & 5.24 & -4.90 & 5.35 & -5.09 \\
\hline 9 & 6.12 & -5.70 & 5.85 & -5.58 & 6.03 & -5.79 \\
\hline 10 & 6.82 & -6.31 & 6.50 & -6.25 & 6.77 & -6.46 \\
\hline 11 & 7.50 & -6.93 & 7.21 & -6.91 & 7.52 & -7.06 \\
\hline 12 & 8.26 & -7.56 & 7.91 & -7.49 & 8.19 & -7.76 \\
\hline 13 & 8.91 & -8.13 & 8.45 & -8.05 & 8.85 & -8.39 \\
\hline 14 & 9.48 & -8.75 & 9.10 & -8.78 & 9.53 & -9.09 \\
\hline 15 & 10.18 & -9.40 & 9.82 & -9.42 & 10.18 & -9.72 \\
\hline
\end{tabular}

Appendix Table 3. Means ${ }^{\mathrm{a}}$ for heat $\operatorname{loss}^{\mathrm{b}}\left(\mathrm{kcal} \cdot \mathrm{kg}^{-.75} \cdot \mathrm{d}^{-1}\right)$ in three replicates during 15 generations of selection for high (MH) or low (ML) heat loss or control (MC)

\begin{tabular}{|c|c|c|c|c|c|c|c|c|c|c|c|c|}
\hline \multirow[b]{2}{*}{ Generation } & \multicolumn{3}{|c|}{ Replicate 1} & \multicolumn{3}{|c|}{ Replicate 2} & \multicolumn{3}{|c|}{ Replicate 3} & \multicolumn{3}{|c|}{ Average } \\
\hline & $\mathrm{MH}$ & MC & $M L$ & $\mathrm{MH}$ & $\mathrm{MC}$ & $M L$ & $\mathrm{MH}$ & $\mathrm{MC}$ & $M L$ & $\mathrm{MH}$ & MC & $M L$ \\
\hline 0 & 125.7 & 122.7 & 121.9 & 120.4 & 119.7 & 119.8 & 123.5 & 127.6 & 124.6 & 123.2 & 123.3 & 122.1 \\
\hline 1 & 128.7 & 123.6 & 124.3 & 131.9 & 134.8 & 128.5 & 131.7 & 128.1 & 122.6 & 130.8 & 128.8 & 125.1 \\
\hline 2 & 130.5 & 127.6 & 123.5 & 143.7 & 134.3 & 130.8 & 143.8 & 131.2 & 131.9 & 139.3 & 131.0 & 128.7 \\
\hline 3 & 141.6 & 133.2 & 126.4 & 142.9 & 143.1 & 130.6 & 138.7 & 129.5 & 126.1 & 141.1 & 135.3 & 127.7 \\
\hline 4 & 134.8 & 134.1 & 126.4 & 142.7 & 136.6 & 132.1 & 147.5 & 141.1 & 127.5 & 141.7 & 137.3 & 128.7 \\
\hline 5 & 144.9 & 140.4 & 126.7 & 144.2 & 136.5 & 126.8 & 148.5 & 132.4 & 124.0 & 145.9 & 136.4 & 125.8 \\
\hline 6 & 145.7 & 130.0 & 118.8 & 148.3 & 129.8 & 122.3 & 143.8 & 134.3 & 120.6 & 145.9 & 131.4 & 120.6 \\
\hline 7 & 147.5 & 132.8 & 119.3 & 153.2 & 135.7 & 119.5 & 155.3 & 136.4 & 120.8 & 152.0 & 135.0 & 119.9 \\
\hline 8 & 151.8 & 142.3 & 120.6 & 158.8 & 135.4 & 119.8 & 154.2 & 138.1 & 120.8 & 154.9 & 138.6 & 120.4 \\
\hline 9 & 156.5 & 134.7 & 123.4 & 151.4 & 130.6 & 112.6 & 160.9 & 132.7 & 113.0 & 156.3 & 132.7 & 116.3 \\
\hline 10 & 161.1 & 127.7 & 113.0 & 155.3 & 130.5 & 113.0 & 169.4 & 134.9 & 117.0 & 161.9 & 131.1 & 114.3 \\
\hline 11 & 157.8 & 128.2 & 115.1 & 166.4 & 131.6 & 113.4 & 164.8 & 134.8 & 112.2 & 163.0 & 131.5 & 113.6 \\
\hline 12 & 160.6 & 126.8 & 111.2 & 166.7 & 137.5 & 114.0 & 168.3 & 135.7 & 115.2 & 165.2 & 133.3 & 113.5 \\
\hline 13 & 164.2 & 132.2 & 106.4 & 171.2 & 136.3 & 109.4 & 173.7 & 130.6 & 108.0 & 169.7 & 133.0 & 107.9 \\
\hline 14 & 170.6 & 131.2 & 107.5 & 179.7 & 138.5 & 110.1 & 174.1 & 129.1 & 107.2 & 174.8 & 132.9 & 108.3 \\
\hline 15 & 177.9 & 134.1 & 105.5 & 178.5 & 136.4 & 109.1 & 181.0 & 134.2 & 107.8 & 179.1 & 134.9 & 107.5 \\
\hline
\end{tabular}

a $n$ each generation and replicate, $n=72$ to 80 for $\mathrm{MH}$ and $\mathrm{ML}$; for $\mathrm{MC}, \mathrm{n}=72$ to 80 for Generations 6,10 , and 15 ; otherwise, $\mathrm{n}=20$ to 35 . b Measured between 20 and 22 wk of age in Generation 0 and between 9 and 11 wk of age for Generations 1 through 15. 